PNL-5811

\title{
Issues in Contracting with Small Minority Businesses
}

\author{
M. T. Wood \\ L. R. Radford \\ L. M. Saari \\ J. Wright \\ M. L. Gragg - Project Manager
}

April 1986

Prepared for the U.S. Department of Energy under Contract DE-AC06-76RLO 1830

Pacific Northwest Laboratory Operated for the U.S. Department of Energy by Battelle Memorial Institute 


\title{
DISCLAIMER
}

This report was prepared as an account of work sponsored by an agency of the United States Government. Neither the United States Government nor any agency thereof, nor any of their employees, makes any warranty, express or implied, or assumes any legal liability or responsibility for the accuracy, completeness, or usefulness of any information, apparatus, product, or process disclosed, or represents that its use would not infringe privately owned rights. Reference herein to any specific commercial product, process, or service by trade name, trademark, manufacturer, or otherwise, does not necessarily constitute or imply its endorsement, recommendation, or favoring by the United States Government or any agency thereof. The views and opinions of authors expressed herein do not necessarily state or reflect those of the United States Government or any agency thereof.

\author{
PACIFIC NORTHWEST LABORATORY \\ operated by \\ BATTELLE \\ for the \\ UNITED STATES DEPARTMENT OF ENERGY \\ under Contract DE-AC06-76RLO 1830
}

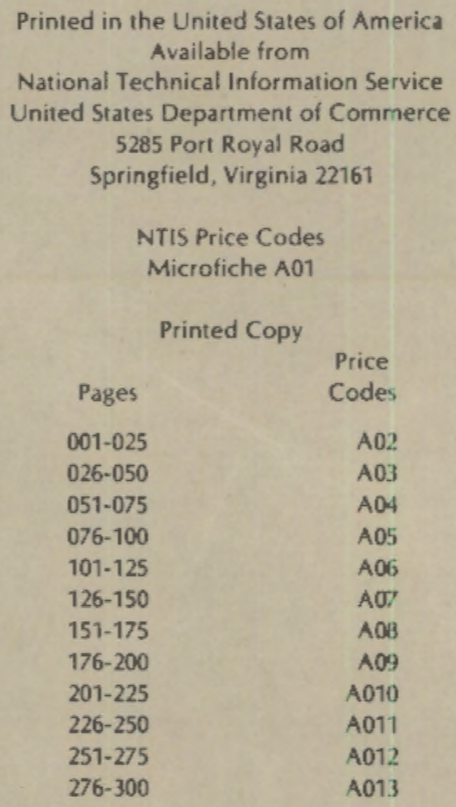


ISSUES IN CONTRACTING WITH SMALL

MINORITY BUSINESSES

\author{
M. T. Wood \\ M. L. Radford \\ L. M. Saari \\ Battelle Human Affairs Research Centers \\ J. Wright \\ Seattle Public School District \\ M. L. Gragg - Project Manager
}

Apri] 1986

Prepared for the U.S. Department of Energy under Contract DE-AC06-76RL0 1830 
เ

- 1

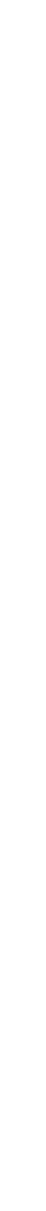


ISSUES IN CONTRACTING WITH

SMALL MINORITY BUSINESSES

\section{EXECUTIVE SUMMARY}

\section{Focus}

The focus of this investigation was to identify issues central to increasing the involvement of small minority businesses (MBs) in federal or prime contracts with the Department of Energy (DOE), as a foundation for designing a program to assist buyers of contracted goods and services. While there are practical limits to what any one program can achieve in increasing small disadvantaged business participation, progress requires understanding the issues and a strategy for solving problems.

Approach

The approach to determining issues involved interviewing the owners of $15 \mathrm{MBs}$, representing a range of businesses, and buyers and purchasing officers from three large DOE prime contractors. The MBs averaged eight years in business and supplied equipment and materials, "high-technology" equipment, and technical consulting services. The owners were interviewed on topics and potential problems in doing business with $00 E$, which were derived from the MB 1 iterature and conversation with experienced buyers and a MB consultant. The interviewees identified issues related to positive working relationships and rated a predetermined set of 27 potential MB-DOE problems regarding their existence and criticalness.

\section{Findings}

The issues identified by MBs were of two broad types. The predominant issues and barriers were associated with their being small businesses. Secondary issues, which aggravated and added to size-reiated difficulties, reflected the disadvantaged status of the business (woman and/or minority-owned). The issues are summarized, by category, on the next pages. 
Small Business Issues

Knowledge of Users' Needs. MBs suffer from: lack of communication; not getting information about general DOE needs or specific procurements; ambiguity in statements of need; lack or difficulty of marketing $M B$ services; lack of centralized information sources; lack of knowledge of MB capabilities, followup of initial contacts, feedback on bids and work.

MBs cannot match DOE needs when the needs and capabilities are not known and acted upon.

Access to First Contract. Politics and human nature make it hard to get a foot in the door. There is a need to overcome tendencies to use "preferred suppljers," to be flexible, take risks, overcome resistance, and match needs to sources of supply.

MBs believe their individual capabilities and performance would make them competitive, if they could get their first DOE job to demonstrate success.

Business Competition. MBs find it difficult to compete with large firms because of price-competition, stereotyped perceptions of MBs, localized marketing, exclusion by prime contractors, and abuses of $\mathrm{AB}$ participation.

MBs want an equal chance, but need limited competition, technical assistance, and cooperation with big contractors.

The Solicitation Process. Issues of paperwork and complexity were of moderate severity, but difficulties do occur regarding timeliness and flexibility of the process and variability in buyers' practices.

MBs believe they can successfully respond with clear DOE goals, fair certification of MBs and evaluation of bids and flexible, responsive buyers.

Financial Difficulties. Small MBs have difficulties with capitalization, bonding, financing, cash-flow, and excessive financer control.

MBs believe their stability and capability extends beyond financial status, and they can gain from business- development assistance and prompt payment. 
Minority Business Issues

Awareness and Sensitivity. Insensitivity to $M B$ perspectives is reflected in misperceptions about "appropriate" minority business; "traditional" minority ventures; and MBs" range and stability. Buyers" awareness may be limited to their "comfort zones," sourcing activities, networking of MBs, and the bureaucratic system.

MBs believe they are not well-known or understood and that greater mutual learning and information exchange is needed.

Attitudes and Motivation. MBs perceive some negative attitudes toward them based in misunderstandings of credibility, performance, and availability. Such attitudes result in their neglect or exclusion. Allegediy contributing to such negative attitudes are: "inequality"/inferiority connotations of "minority-business" designation; and goals based only on "good faith." MBs perceive these attitudes to be occasionally manifested in game-playing, subterfuge, and overweighting of negative information about $M B s$.

From this range of $M B-D O E$ issues, several potential problems stood out in the ratings as being the highest-priority because they are real and critical. Those issues in priority-order were: (1) not getting information about procurements; (2) inability to compete against bigger companies; (3) prime contractors not working closely with MBs; (4) not being able to sustain costs when it takes so long to get paid;

(5) inconsistent application of policies and regulations; (6) buyers need to learn more about minority businesses; (7) seeking DOE contracts is time-consuming and expensive; and (8) a mechanism is needed to match $\mathrm{MB}$ capabilities and DOE needs.

Buyer Issues

While buyers tend to support minority-business involvement, they do so in a context of maximizing their business efficiency in terms of price and quality. Special minority-business programs may add difficulties to the buyers' jobs, where goals conflict with philosophies or practical business decisions. Buyers see minority programs as reflecting top-down enforcement but not implementation assistance. Buyers are often pressured "middlemen" between management's emphases and technical users' needs and 
preferences. The ease of involving MBs varies with the types of products and services for which the buyer is responsible.

Buyers' frustrations in dealing with MBs include: MB supply (too few) in the particular procurement field; MBs' lack of knowledge about doing business with DOE; inadequate bid responses from MBs; lack of MB follow-through or delivery; unrealistic bid pricing; MBs' spreading themselves too thin when they expand their businesses; and MBs" capabilities and responsiveness.

Buyers suggested continuing or developing remedial actions, including: negotiated (not top-down) goals; set-asides where the supplier-base provides sufficient competition; telephone bids; standardized bid procedures; positive reinforcement from buyers management; technical assistance for buyers; better sourcing and identification of successful MBs; mechanisms (conferences, trade fairs) to bring buyers and MBs together; and general organizational support and outreach.

\section{Implications}

Strategies for resolving the $M B-D O E$ issues involve buyer assistance and broad agency actions. The foci of buyer assistance possibilities include: information exchange, communication and feedback; expanding and using MB-sourcing information; flexibility and risk-taking; qualifying and assisting new suppliers; interpersonal skills, awareness and sensitivity; and monitoring and expansion of MB programs. DOE initiatives, many of which have been implemented, would include: outreach programs; technical and business assistance; goal-explication and enforcement; communicating and specifying needs; optimizing procurement, certification, "set-aside," and waiver guidelines; facilitating payment and support with financial backers; and strengthening women-and-minority-business program accountability and support.

A subsequent report will describe the design of a technical assistance program to assist buyers in working with small minority businesses, based on the issues faced by the buyers and MB owners. 


\section{TABLE OF CONTENTS}

$\underline{\text { Page }}$

EXECUTIVE SUMMARY . . . . . . . . . . . . . . . . . . i i

INTRODUCTION

Focus of Project: Definition of MB Issues . . . . . . 1

Project Approach . . . . . . . . . . . . . . . 3

FINDINGS: ISSUES FROM THE MINORITY BUSINESS PERSPECTIVE . . . . 5

Smarl Business Problems . . . . . . . . . . . . 5

knowledge of users' needs . . . . . . . . . . . . 5

Access to first business opportunities. . . . . . . 7

Business competition with large companies. . . . . . 8

The solicitation process . . . . . . . . . . . 10

Financial difficulties . . . . . . . . . . . . . 12

Minority Business Problems . . . . . . . . . . . 14

Awareness and sensitivity. . . . . . . . . . 14

Attitudes and motivation to use MBs . . . . . . . 15

Lack of accountability and support . . . . . . . . 17

Minority Businesses' "Own" Problems . . . . . . . . . 18

MINORITY BUSINESSES' REACTION TO GOVERNMENT TOOLS/PROGRAMS . . 21

TO HELP BUILD RELATIONSHIPS

ISSUE PRIORITIES BASED ON MB RATINGS . . . . . . . . . . 23

Highest Priority Problems . . . . . . . . . . . . 23

Secondary Priority Problems . . . . . . . . . . . 26

Lesser Priority Problems . . . . . . . . . . . . 27 
Page

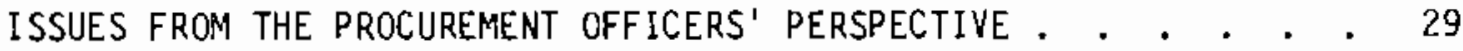

Attitudes and Support of MBs . . . . . . . . . . . 29

Concerns About MB "Programs" and Goals . . . . . . . . 29

Supportive Regulations . . . . . . . . . . . . . 32

Difficulties in Dealing with MBs . . . . . . . . . . 33

Tools for Dealing with Problems . . . . . . . . . 35

THINKING TOWARD SOLUTIONS . . . . . . . . . . . . . . . 39

BIBLIOGRAPHY . . . . . . . . . . . • . . . . . . 43

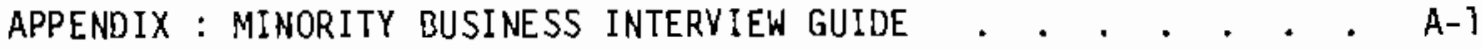




\section{LIST OF FIGURES}

Figure

Page

1 Rating Scales for Minority Business Problems . . . . . 24

\section{LIST OF TABLES}

Table

Page

1 Mean Ratings of DOE/MB Business Problems by . . . . . . 25 Minority Business Leaders

2 Mean Ratings by Buyers of Problems in Dealing . . . . . 36 with Minority Businesses 


\title{
ISSUES IN CONTRACTING WITH \\ SMALL MINORITY BUSINESSES
}

\author{
INTRODUCTION
}

Focus of Project

Both sma11 minority businesses (MBs) and the Department of Energy are concerned about enhancing the participation of MBs in contracted work for the government. From the $N B$ perspective, the concern sterns from a desire to succeed in the business world. From the government viewpoint, there is a need to maintain and increase $M B$ involvement based in law and social obligation.

While DOE, and other government agencies, have significant $M B$ programs underway, federal reports of participation show room for improvement in many areas (U.S. Small Business Administration, 1985). The major kinds of activities that buyers are performing to enhance $M B$ participation include:

- Investing money in $M B$ firms, through investing in $M B$ banks, offering SBA (8a) loan programs, awarding training grants, private-company and union investment in MBs, offering financial incentives to MBs (below-prime loans, loan pools), and contract set-aside programs.

- Identifying and certifying MB firms, through outreach programs, developing directories of MBs, and supporting MB conferences and councils.

- Developing MB capabilities with technical assistance, through workshops, trade fairs and various programs of business-development assistance.

- Modifying contract regulations, including streamlining, providing procurement assistance, preparing buyer guides, establishing faster payment procedures, allowing fees on grants, and relaxing competition in some circumstances.

- Encouraging new mechanisms for MB involvement, such as "incubating" (where two firms share overhead costs), and "buddy systems" (where an MB graduating from 8a status uses a new MB on a project). 
- Increasing buyer accountability, by requiring proposals from potential prime contractors to show planned MB participation, and by using MB participation as an evaluation criterion in SES (senior executive service) performance contracts.

The DOE's efforts reflect emphases similar to those described above. Programs administered by DOE's Office of Minority Economic Impact include:

- Research on effects of national energy programs on minorities

- Technical assistance to minority education and business

- Loans to MBs

- A minority energy information clearinghouse

The focus of the present investigation was to jentify issues centra] to increasing the involvement of $\mathrm{MBs}$ in federal or prime contracts, as a foundation for designing a program to train buyers of contracted goods and services. The projected steps in this overall business-enhancement effort involve:

1. Identify the issues, probiems, and needs of $M B s$ and buyers related to greater involvement of MBS in DOE work

2. Design a training progran to assist buyers in dealing with MBs

3. Develop, administer, and evaluate the training

4. Involve buyers and MBs in joint activities to conceive new ideas about and solutions to energy-related problems

The present project focuses on steps 1 and 2 . The long-term goal of the project and the additional activities is to increase the depth and breadth of MB participation in DOE business.

Clearly, there are practical limits to what can be achieved with this effort. Given the scope of the problem, variables contributing to $M B$ involvement, and constraints in the system, objective increases in long-term $M B$ participation may be slow to evolve, and may represent only marginal gains in proportions of business needs served by MBs. Nonetheless, majntaining and accelerating progress require an understanding of issues and a strategy for solving problems. 
Project Approach: Definition of MB Issues

The derivation of issues related to the involvement of MBS in DOE work reported here was based on a series of structured interviews with owners of MBs and with buyers of contracted work for DOE prime contractors. The sample of MBs consisted of 15 firms located in the Seattle-Tacoma, Washington area. While the sample imposes geographic constraints to generalizing the findings, it did represent a range of businesses. The firms included nine suppliers of equipment (industrial, electronic, durable goods, scientific, building, office, and other supplies); three suppliers of "high-tech" goods (computers, software, information processing); and three providers of technical/expert consulting services in areas such as waste management, environmental science, planning and impacts, health hazards, accounting, and appraisal. The firms had been in business for from 2-50 years. The 50-year old firm was an "outlyer"; the median time in business was 8 years. The firms had a range of experience in contracting with: (1) DOE directly; (2) prime DOE contractors such as Rockwell, UNC, Battelle, Westinghouse; (3) other energy agencies (BPA, City Light); (4) the military (Army, Air Force); (5) other government agencies (state and county); and (6) industria] manufacturers. The "typical" MB is a 5-10 person firm distributing goods or providing technical services.

The sample of buyers consisted of 14 officers from three large DOE prime contractors in Washington state. The firms provide research, supplies and facilities management to DOE projects in the Richland (Hanford) area. Four of the officers were experienced managers of procurement operations; the other 10 were direct buyers of goods and services including: small purchase orders and large-volume supplies; durable goods (tools, electronics, office supplies) and research or technical services; and directly-purchased supplies and subcontracted services. The buyers varied in experience, but all had some experience contracting with minority businesses.

The interviewees, both MB owners and DOE buyers, responded to a structured interview administered by one of the researchers during a $1-2$ hour interview. The items on the questionnaire were developed from a review of the literature on $A B$ involvement in contracts, and preliminary conversations with experienced buyers and a MB consultant. The 
questionnaire contained both "open-ended" questions with qualitative answers, and ratings of business problems with quantitative responses. The open-ended portion of the interview asked questions concerning:

- Factors contributing to positive and negative working relationships with DOE (MBS), based on recall of particular incidents

- Reasons why DOE-MB business relations are not always successful

- How procurement rules ought to be changed

- Hurdles to doing business with DOE (MBs)

- Tools that have been found helpful in dealing with DOE (MBs)

- Attitudes toward informal bidding processes and IAB set-asides

- Other problems and suggestions

The "ratings" part of the interview involved rating potential problems on two five-point rating scales: (1) one asked for the extent to which the problem/situation exists; (2) the other rated the perceived criticalness of the problem. A copy of the interview guide is shown in Appendix A. 
FINDINGS: ISSUES FROM THE MINORITY BUSINESS PERSPECTIVE

The issues of concern to minority business owners reflected two broad classes of problems, based on the primary reason that those problems exist. The first, and broadest, set of issues dealt with problems associated with being a small business. Regardless of their minority status, these businesses experience difficulties in working with a large buyer-organization because of their size. Indeed, small-business problems tend to override any uniquely minority-business problems. These business issues embraced concerns related to being too small to understand and interact or compete with large organizations, and to being too new to have experience in working through the bureaucratic system or developing their businesses to be compatible with the marketplace. Five kinds of small-business problems affecting MBs are discussed in the next sections.

The second set of issues reflect attitude problems that exacerbate small-business problems for minority business persons. These are discussed after the presentation of small-business problems.

Smal1 Business Problems

Knowledge of users' needs. This is a major concern of small minority businesses that makes it hard for them to respond with the right goods or services. It is basically a communication problem that represents DoE not publicizing its needs, MBs not being able to determine what those needs are, and/or MBs not making their capabilities known. The key issue, noted by half the firms interviewed, is that MBs typically do not know what DOE (or its primes) needs. Therefore, they find it difficult to develop appropriate product/service lines, market their capabilities, or find the right proposal-requests to answer. This lack of specific-need knowledge comes in two forms. First, there is a lack of general knowledge in the MB community about what types of needs (e.g., product indexes, lists, service types) DOE must regularly fulfill, independent of particular solicitations. Some MBs report that they only receive "huge" RFPs, not stable lists of product types or service areas required by DDE operations. Thus, it is difficult for the business to build staff-groups or product inventories to meet anticipated needs. It must be noted, of course, that solving this problem is easier for some of DOE's activities 
than others. The situation could be improved for repetitive product or support-service needs. Providing long-term needs information is more difficult for research and development. Secondly, solicitations, when they do appear, are of ten ambiguous in their terms for product-specifications or service-related tasks. Even if the MBs receive an order, they often have to phone to clarify confirmation of the order.

Several firms noted that they have benefited from good communication of OOE's needs. That communication is served through informative DOE inquiries that serve to bring about a need-product match and that provide concise, complete bid-relevant information. Positive DOE-MB relationships are also fostered by interpersonal information exchanges and ensuing good rapport between the $M B$ individuals and the buyers. These exchanges can occur in structured trade fairs, meetings with buyers, meetings with large ("prime-contractor") organizations doing business with DOE, and in timely communication of needs that allow businesses to adjust, plan, and respond. However, such initial contacts and attempts to bring DOE and lilss together often lack the required followup to put business transactions in place. For example, one interviewee reported getting business from three out of 50 companies he had met at fairs and conferences. Another noted that it took a year to get on a company's "bid list," after which he still has received no orders. Smail minority businesspersons beilieve they suffer by not knowing the buying officers, or the product/service users within DOE organizations. The lack of a central information source, perhaps coupled with incomplete knowledge of $M B$ capabilities, results in MBs either not getting inquiries, or in DOE not getting their information to the right (most appropriate) $M B$ people.

The majority of MBS interviewed cited the need to make DOE programs and activities better-known. Moreover, in their ratings of potential business problems, needs-awareness stood out as a key problem. MBs felt that DOE doesn't get the word out to them on upcoming procurements (mean rating $=4.5$ on the 5 -point scale of problem existence) and that such a situation is a critical factor hindering positive working relations when it occurs (mean criticalness $=4.8$ ). Similarly, the MB interviewees believed that it is difficult for them to get procurement information (4.1), which is also a critical inhibiting factor (4.5). MB representatives urged more and better communication, so that needs can be 
recognized and put into government and business program-design cycles. They suggested getting buyers in touch regularly with minority businesses through true outreach programs. That would allow buyers to get to know minority businesses, and the MBs would have an avenue for getting their product knowledge to the buyers. The same process should apply to the objective of getting prime-contractor firms in situations to meet and work with MBs with whom the primes could subcontract.

In addition to comunicating user needs at the front end of the business-generation cycle, comilunication may be lacking after contract decisions. Some $M B$ firms suggested the need for better feedback on why they lost bids, and for regular communication during contracts to identify problems. Typically, they learn of a problem in their performance via letter, or when they do not get paid. MBs want to satisfy users' needs; they urged better definition and communication of those needs, and feedback on whether they are meeting the needs.

Access to first business opportunities. A major difficulty faced by many MBs is the inability to match their interest in doing business with DOE with a first-contract opportunity. They say they want to work with $D O E$, but can't get a contract. Those businesses reported seeking out business or applying for procurements without success. Part of this problem is related to the foregoing issue of communicating DOE needs and MB services. However, the "access" problem goes beyond communication. To paraphrase one MB, "Even when we are known, we don't get called with orders". Trying to get in the door the first time in the face of buyer nonresponsiveness was cited as a factor contributing to poor DOE- $\mathrm{MB}$ working relations. A possible underlying problen in this regard is considered to be extreme competition among $\mathrm{MBs}$, and the practice of buyers' using preferred suppliers. If buyers have a preferred supplier whom they know, have used successfully, and can readily engage, they are iikely to not open the door to new firms. This difficulty is compounded when MBs lack access to procurement officers for direct communication. The preferred-supplier problem is sometimes characterized by "subtly" favoring a preferred bidder. For example, "al ternative" supplies/materials may be disallowed in procurement competition, but then accepted (after the fact) from the preferred-bidder who wins the award. 
MBs acknowledge that part of the problem is "human nature"; it is easier for buyers to work with familjar suppliers. But part of the problem is also thought to be political, in that politics often override low prices as a selection criterion. Ironically, MBs see a "reverse equal-opportunity" effect; they say they would win often on low bids, but buyers seek low prices from their preferred (sub-) contractors. Government buyers are seen as lacking premiums for flexibility, risk-taking with unknown $M B S$, and distribution of business throughout the private sector.

MBs occasionally feel expressly prevented from first-access opportunities by majority-firm prime contractors. In some cases, those firms are seen as actively resisting laws and regulations that try to force small minority business participation. Prime contractors, according to some MBS, tend to "rationalize away" MB requirements and el iminate MBS from competition.

Access was cited as a hurdle to doing business with DOE by most companies. Several indicated that they had to counter by directing their marketing efforts to the (better) private sector. Trying to get DOE work was seen as frustrating, al though MBs acknowledged that "time-in-business" affects their perspective on DOE (older businesses may not be as frustrated). MBs need access to end-users to learn their needs and get their first contract. They suggested better matching of DOE needs and $M B$ products. Current systems for doing that, like PASS, were considered outdated, incomplete, or not effectively used.

Business competition with large companies. Like other small businesses, MBs often simply cannot effectively compete in the supplier marketplace, if large organizations (primes, manufacturers) offer the same products and services. The seriousness of the competition-problem varies across industries. MBs have been able to compete with large firms in labor, low-skill service areas (e.g., janitorial), but not in providing sophisticated technologies (information processing); competition is also considered difficult in the construction and professional/technicalservices industries. Part of this supplier-sector difference may be due to common stereotyped perceptions of expected or appropriate minority enterprise (see section on attitudes, p. 15). 
Even though differences exist across types of companies, the overall severity of the issue is critical, as depicted by the MBs' ratings of problems. The difficulty of competing with larger companies was considered prevalent (4.4) and critical (4.5) by the MB interviewees. Some have tried joint-ventures with large prime contractors; but it is commonly agreed that primes don't work closely enough with MBs to meet contract requirements $(4.3)$ and that such a situation represents a critical problem (4.4). Moreover, joint-venture attempts often result in $M B$ subservience to their partner.

The competition with large firms is characterized by either the big firms' disinterest in, or attempts to exclude, MB competitors. It is particularly difficult to do business or compete with manufacturers because of price competition. The MB can get "frozen out" by not getting access to products at the right prices to distribute to DOE or other buyers. MB distributors of goods report that it takes two-three rounds of negotiation to get quotes from manufacturers for resale to DOE. The fIBS resort to innovative ways to underprice manufacturers and solicit their "cooperation" by hitting them where it counts--in the pocketbook. A related exclusionary aspect of the competition problem is the big firms' tactic of considering their products or techniques proprietary, thus stifling their use or adaptation by other (e.g., MB) firms. In some cases of patent or copywrite, this is, of course, business-appropriate. In other cases, it may involve misuse of proprietary rights. The MBs also reported being constrajned by "localism"; it is hard to get business outside one's city. Here, size, marketing, lack of contacts and business costs are likely bases for the MB problem.

It is generaliy accepted by MBs (with some exceptions) that they cannot and will not compete with the big firms for DOE business. It is believed by some that, since DOE is itself a large business, its buyers want to deal with small business as if they were also large, for example, in taking things back, modifying product specifications, negotiating contract changes, etcetera. MB leaders suggested that DOE should not expect small firms to compete on the same terms with big ones. Rather, procurement officers should realize that MBs are not looking for jobs that they cannot staff or deliver. This MB viewpoint, incidentally, counters a contrasting view of some users (as reported in the literature) that MBs 
tend to overextend themselves on the scope or size of contracted activities. By competing as small firms, some MBs are nowever, looking for larger-volume orders. They see themselves as getting "nickel-anddimed," and as not landing the big, serious jobs that carry greater import. to DOE and financial gain to the $M B$.

In addition to encouraging realistic DOE expectations, the MBS generally endorsed government's technical assistance efforts. Al though some were pessimistic about the current value of technical assistance, others cited helpful assistance, especially from the Small Business Administration, in helping them develop their businesses. At the same time, however, a few noted that 8(a) programs (SBA programs for small minority business) can be difficult to use. That is, those programs are seen as difficult to enter (qualifications requirements) and difficult to "escape" (or graduate to being independent of their support). It was also suggested that greater efforts to match MBs with major firms for project activities would help alleviate the competition probiem.

The solicitation process. Another set of $M B$ difficulties deals with government regulations, the solicitation/procurement process, and bidding for work. One aspect of this problem concerned the volume of regulations and paperwork requirements. However, opinions on this matter were mixed, and the "paperwork-problem" was rated as one of only moderate severity. The mean ratings for the existence of excess and complicated paperwork were 3.6 and 3.4 respectively (on the 5 -point scales), and their criticalness was of the same general order.

In their interview comments, MBs noted regulations and paperwork are a problem, but those features are also considered a "part of the territory" that all businesses face. Some took a stoic stance that MBS should do their homework to understand and comply with such requirements. They suggested that the paperwork volume scares business people, but that, in reality, there are only a few key pages with which they must cope. others argued that the problem is more intense for small MBs that do not have sufficient specialized staff to handle that element of work. Clarity was more often noted as an issue than volume of paperwork. Terms and certifications were often considered confusing ("You have to be an attorney to understand them"). Clear terms were cited as a contributor to positive relations in one instance. Another concern related to equal 
treatment in bid responses. That is, small MBs should not be subjected to paperwork requirements that other firms are not. The process of seeking contracts with DOE was considered time-consuming and expensive (mean rating $=4.2$ ).

The solicitation process was seen to suffer from an occasional lack of timely bid information. The problem of too-little lead time was especially apparent with formal RFPs. However, most IMBs were not troubled by a timeliness issue. Everyone interviewed favored informal telephone solicitation/bid practices. In one instance, such a process, where the buyer accepted a telephone bid with written followup confirmation, contributed to positive working relations. Although the informal process is supported, it is alleged to have helped only on a small scale. It should be expanded to involve many $M B s$, not a select few, or one who is to receive a big contract. In addition to overcoming time delays and paperwork, the informal-telephone process also helps to clarify DOE needs and products available from the $M B$.

Another regulation/solicitation practice generally favored by MBS is that of "set-aside" procurements for small MBs. Such set-asides help to counter the "favorite-supplier" syndrome. However, this support is qualified by the fact that some MBs are philosophically opposed to set-asides because of their restrictive connotation. Indeed, backlash to set-asides is causing some in government to rethink the matter in terms of a supportive notion of "limited competition" rather than "exclusion" of certain types of businesses. It was also suggested that set-aside provisions focus on dollars-to-MBs rather than on percentage set-asides which can result in small dollars to ins.

The MBS were asked what regulations they would like to change. In general, they found this difficult to answer. The rules, programs, benefits, and reports on what actually takes place are often not clear. Therefore, they are not sure what or how to change. Rather than "rules" being the problem, the issue is considered one of flexibility in interpreting and applying the rules to meet their intent. Uver 20 percent of the interviewees said, "Don't change the rules.. . ensure that people understand in what ways the rules are flexible . . . and enforce them." Buyers, they believe, should be flexible and open-minded on bid processes, answering questions, etc., but should take a hard-line stance against 
subverting the rules, such as through using equivalent materials, comparing MBs out-of-category, and similar exceptions or abuses.

A large part of the flexibility issue has to do with people rather than written rules. It is a common perception that buyers are quite variable, and that many are rigid and unwilling to take risks. At the extreme, some Mibs question the degree to which inspectors and certifiers stay on top of their jobs. More typically, the concern is that buyers seem unwilling to move outside their pre-established "comfort zones" of known, familiar contractors. Such a situation adversely affects soliciting new bidders or giving serious consideration to new firms that submit bids.

MBs felt that the solicitation process could be improved if DOE would either concretize its needs or allow alternative or qualified bids. Moreover, the types of projects for which MB responses are solicited should not be limited. Some MBs said that seeing a few large RFPs, instead of many small ones, makes it hard to conpete; others felt they were excluded from getting the bigger jobs. Problems in the solicitation process depends on the type of business and situation. However, HBS generally would prefer clearer and more uniform procurement guidelines. With respect to minority-business (or "MBE-program") goais, DOE should let the business community know how those goals are set and evaluated, so that MBs can "estimate our chances." There is a related concern that "good faith" goals are not met; more mandatory sma11/minority business goals are needed. Similarly, the state and local-agency procedures for certifying MBs need to be improved to ensure legitimacy of categorization. That is, some certified "small businesses" are not smal1, and some "minority-owned" businesses are in reality fronts or shams. (Information beyond the interviews suggests that such situations are improving, al though abuses persist in getting certified as women-owned businesses.)

Thus, the central concern about regulations and solicitation is not that the rules are wrong, but that they need to be communicated, carefully and flexibly applied, and enforced.

Financial difficulties. A large segment of the problem MBs face in getting and sustaining business relates to their financial limitations. This, of course, is a typical small-business problem and one that extends 
in some respects beyond DOE control and assistance. Some things, however, can be done to improve the situation.

The two central aspects of the MBs' capital problem involve initial bonding and capital acquisition, and ongoing cash-flow solvency. Their linkages with banks to provide the capital, and with clients to pay for services, are critical relationships. Most MBs cite difficulties in getting bonding and loans and the need for help in financing business dealings. They view the banks as tight on loans and close on scrutiny. Examples were described where banks were atypically quick to call-in debts. One minority businessman compared his situation to that of a large local company. The large company had been operating in red ink for months; the bank called the MB within two days about a $\$ 150$ overdraft. Banks do not deficit-finance MBs. The MBs' difficulty in getting money is related to their size, lack of collateral, and lack of track records as new businesses. Some suggestions from MBs to improve this situation involved changing evaluation criteria and getting government help. By changing evaluation, they mean making lenders realize that small businesses are financially unstable and change the "track record" focus to performance and people rather than dollars. Government assistance was considered feasible, if moneys spent on investigating MBs could be redirected to pools for bonding assistance. More generally, the MBs counsel government support services for bonding, consulting, and business-development technical assistance.

Maintaining cash-flow is also difficult. "We can't develop markets under pressure to pay our bills." The MBs own business practices sometimes contribute to the problem. To be competitive, they attempt to discount their prices; but, when they are smalt, that eats into their profit margin. The more resolvable part of the problem is the client's slowness to pay. With slow payment, the MBs cannot absorb interest costs and establish cash-flow to buy goods for resale to DOE (or others). Slowness to pay was the most critical post-contract problem faced by MBs. They rated "taking too long pay" as frequent (mean $=4.1$ ) and extremely critical (4.7). Positive working relations have accrued when buyers have paid on time. Some of the cash-flow improvement strategies have involved: early payment provisions; paying major suppliers directly for goods purchased through $A B$ distributors; paying MBs' freight costs at 
government rates to make the MBs' bids competitive; and generally seeking financially advantageous ways to contract with MBs.

Minority Business Problems

In addition to being confronted with business problems attributable to their being small, minorities believe that their minorityclassification or status precipitates other kinds of problems, which exacerbate or add to their other business problems. Being a small minority business does make it more difficult than being (just) a small business. The two classes of "minority-related" problems concern others': (1) awareness and sensitivity to MBs; and (2) attitudes toward MBs and motivation to use them.

Awareness and sensitivity. According to MBs, they are commonly misperceived as to history, business acumen and business intent. Some carry misperceptions of "appropriate" MB enterprises; MBs are viewed as unsophisticated and appropriately engaged in janitorial services, fast-food franchises, and the like. They are not seen as in the mainstream of high-technology business (e.g., computers) or professional services. Some MBs beljeve that DOE will not work with MBs in so-called "nontraditional" areas of business for minorities.

In this regard, MBs report major variability and inconsistencies in the application of regulations among purchasing officers. MBs rated inconsistency as an extant and important problem that occurs both in bidding for contracts (means $=4.2$ exists; 4.3 critical) and in working on them $(4.3,4.4)$. Some buyers seem "comfortable" working with MBs; others do not. Awareness allows MBs and buyers to discuss and resolve problems. Awareness and sensitivity, combined with good past performance, helps encourage buyers to spread the word, or develop MB-sourcing networks. This stimulates then to use more MBs and other buyers to solicit MB participation. One interviewee noted that awareness is present at the DOE headquarters level, but it gets lost in the lower levels of bureaucracy. Purchasing officers are often insensitive to the range and stability of $M B S$, and this insensitivity can be insulting in relations with MBs. The lack of awareness may produce a situation where contracting risks are not communicated to MBs. Then, the MB may underprice a bid, fail to perform or lose the job, and engender negative relations with $D O E$. 
Several MBs felt that DOE lacks interpersonal skills and experience in dealing with MBs and their minority representatives. Buyers need to work closely with MBs to understand their sensitivities, history, and atmosphere. Some noted that when buyers have done this, positive working relations have followed. Before contracts are let, buyers can learn about minority businesses and help to ensure mutual understanding through contract negotiations. Laws, like the federal public law 95-507 or the Washington State Business Partnership Act, may help. But the key to successful ventures is the buyer who must deal with the MBs. As one person put it, buyers need to communicate. . "more sensitivity, less (sic) nonsense".

Attitudes and motivation to use MBs. Even more severe a problem than a lack of understanding MBs is the more direct and adverse issue of openly or subtly precluding $M B$ involvement because of explicit negative attitudes about MBs or implicit biases that lead to oversight of those firms.

Some MBs believe there is an inherent iack of confidence in MB success that is assumed by some buyers (one noted, however, that some agencies show confidence, patience, and support). This lack of confidence in turn generates an expectation among MBs that DOE does not do business with them; hence, the MBs opt not to bid on DOE work. Several interviewees said that the major problem is DOE's (and others') firmly entrenched attitudes that neglect or inhibit $M B$ involvement. That problem is not a central thrust of DOE business, but is buried in the bureaucracy. If $M B$ involvement is not expected of buyers, by DOE management, then buyers won't bother to involve MBs. Sound organizational practice suggests that government should show concern at the top, with management setting policies to give MBs access to business. Without that commitment, many buyers just may not care; they may lack the willingness to try to involve MBs. In effect, there would be no operative "good faith" to use MBs. Some buyers, MBs believe, think that MBs cannot compete, so they do not solicit the MBs. Those buyers fail to realize the $M B$ 's viewpoint that a $M B$ will not typically overextend itself. Often, MBs can beat other firms' bids, but the tone of purchasing officers is not supportive of their trying. Again, this situation ties back to 
management. DOE and their prime contractors allegediy do not stress the importance of MBs and tell their buyers to make minority business enterprise (MBE) programs work.

Negative attitudes toward MBs are also believed to pervade the majority-firm, prime-contractor business community. Many firms have negative attitudes toward "minority business" programs. MBs often try to joint venture with majority firms because the MBs do not believe that the government wants them to have a contract. However, the major firms' attitudes mitigate the success of joint ventures. In some cases, the attitude reflects indiscriminatory stereotyping that a business is "black" or "foreign"-owned, and therefore inferior. The designation "minority business" is perceived by many to connote "inequality," at the same time that society is striving to enforce equal opportunity. Companjes attitudes may be condescending, ejther toward MBs (they'11 take the benefits and go along with the majority company's program), or toward DOE (MBE programs are welfare giveaways). Such views contradict the MBs' own attitude that they want an equal chance to succeed in business. Being perceived as different makes success more difficult, in that some large firms' (and government) representatives believe that a mistake by a MB carries twice the adverse impact as others' errors.

Negative attitudes towards MBs occasionally results in their abuse. MBs reported feeling that they "get used" to satisfy attempts to meet MBE programs' goals or procurement regulations. They feel used in satisfying "statistics," "goals," or "clauses." Getting used occasionally involves misrepresentation. The buyer may call or solicit the MB to satisfy requirements, then order products directly from the manufacturer. Buyers may involve MBs in contracts to satisfy goals, then undermine those contracts. Such a case was reported, where a prime subcontracted with a $M B$, then changed delivery/payment terms so that the $M B$ could not meet them; the prime then took over the subcontract. MBs believe that prime contractors will abuse them by getting information or expertise from them under the pretense of a following subcontract, which then does not occur. Abuse may also come from majority investors in MBs. Incidents were reported where investors (whom MBs often need), allegedly take over control of the firm, use it as a MB "front," and in some extreme cases, 
embezzle funds from the MB. MBs often feel caught in this regard. They need capital, but do not want to take proceeds and be a front for others" control.

There was some counterreaction to this negative situation. In an example of positive working relations, a $M B$ cited a case where the buyer admitted "up front" that he was involving them because of a MB procurement clause; but he also viewed it as a chance for the MB to perform well and secure follow-on work with the buyer. Similarly, some MBs report a situation with buyers of "fair treatment," "no game-playing."

For some MBs, part of the attitude problem may be attached simply to the designation "minority" business. There was a generally high levei of criticalness attached to that designation in the MBs' problem ratings (4.0), but there was also substantial variability among the viewpoints of different MBs. Most of the MBs felt that "minority business" is a detriment connoting "less-than-equal" and a reputationally bad status. Some suggested they should be treated as any other "small disadvantaged business." They pursue equal chances to business access and beljeve they should win contracts with low bids, not their minority status. 0thers, however, were willing, and think it is fair, to capitaiize on the advantages of being a MB. In a positive sense, those people see their minority status as a birthright and useful for securing business opportunities.

Lack of accountability and support. Many of the MBs reported that business problems with the people with whom they deal (buyers, contract officers) relate to a fundamental organizational problem that extends beyond those contacts. That is, for MBE programs to work, those who deal directly with the businesses must have complete support of their manager, and be held accountabie for their performance in fostering minority business contracts. The comitment and accountability should start at the top of DOE and majority prime contractors and filter throughout the line and contracting components of the organizations.

The MBs suggested a need for stronger accountability; they typically see no incentives in the system for buyers to make the extra effort that may be required to seek out and negotiate with MBs' in product or service specialty areas. Three specific suggestions offered to buttress accountability were: (1) contacts with MBs should be a factor in buyers' 
performance evaluations; (2) managers should leverage buyers for frequent and regular reports of performance relative to percentage goals; and (3) files should be kept, circulated and used on MBs' quotes for future reference, communication, and sourcing.

Taking this kind of accountability a step further, and in a frame of positive motivation, buyers could communicate, network, and promulgate relations with MBs among their colleagues. With a record-keeping system and communication, a network could be bui7t based on MBs' successes in contracts. The MBs urged that we need a true minority business program with the support, backing, and clout of government and corporate management, prime contractors, and bank officers.

Minority Businesses" "Own" Problems

The problems cited so far in the arena of contracting with MBs have attributed, or implied, causes within the organizations that deal with MBs (or fail to do 50). Moreover, the focus of this research effort is to examine issues that $D O E$ can help resolve. However, the MB interviewees were also self-critical and mentioned problems that they had to manage for themselves in operating their businesses.

Hard work and business acumen is necessary for any business organization. MBs recognize that they must: do their homework to understand and work within the system; be price-conscious in their bids and work; emphasize quality of work and performance. They also noted their own needs to create demand for their product or service. Some felt that while they know how to advertise, they find it hard to implement marketing because of the expanse of the procurement system; they need to get better information from DOE and to educate themselves. The typical strategy for dealing with system complexity is to emphasize marketing the local area, which limits many opportunities with DOE.

To the extent that MBs want to be evaluated in terms of their individual capabilities, rather than their firms' experience, they need to assemble skilled work teams and surround their leadership with expert staffs.

The basic message conveyed by MBs in this regard is that, as government provides better opportunities for MBs, the MBs must be prepared to capitalize on those opportunities and meet contract obligations well. 
Such a situation could help create a cycle, where the MBs' capabilities generate long-term contracts, which allow for staging of activities, confidence-building, and the establishment of relations with other organizations. 
$\wedge$

* 


\section{MINORITY BUSIMESSES' REACTION TO GOVERMMENT TOOLS/}

\section{PROGRAMS TO HELP BUILD RELATIONSHIPS}

At the outset of this report, some objectives and activities of DOE/MBE programs were summarized. Many of the suggestions offered by the MB presidents were consonant with what DOE is currently trying to achieve. However, their reactions to questions about "tools" or programs that could be used to enhance doing business with DOE revealed a general lack of awareness, or exposure to, such tools or government programs. Seven of the 15 firms had no experience with programs aspects that would be helpful. A few said they relied on their "own resources."

While technical assistance to MBs was generally endorsed, some MBS said "we don't need more programs." Laws can help, but even new initiatives may be problematic. The "Business Partnership Act" being reviewed in Washington State, for example, has generated diverse opinions about whether it would really help MBs, or just provide a convenient way for large firms to link with select MBs to satisfy minority procurement goals. Laws and guidelines that focused on "dollars-to-MBs," rather than percentage goals would be preferred. Beyond the laws, the key to success is alleged to be people. That involves knowing buyers, who become good people with whom to work after initial acquaintance is made.

Communication tools were cited in several respects. Program goals, mechanisms and opportunities need to be communicated to MBs. Better MB-sourcing mechanisms are needed. The concern was expressed that PASS is not extensively used, and "buddy-systems" predominate solicitation of MBs. DOE could also help MBs indirectly by promoting them in relations with majority firms and large prime contractors. 


\section{ISSUE PRIORITIES BASED ON MB RATINGS}

As described earlier, in addition to mentioning and describing their business problems, MB leaders also rated a set of potential problems that had been identified from the trade and professional literature. Some of those ratings were cited in previous sections of this report to underscore the importance of the issues that the MBs were offering from their experiences. This section further summarizes those ratings, since they reflect a standardized assessment of problems made by a broad sample of MBs.

For each potential-problem statement, two ratings were made: (1) the extent to which the problem exists; and (2) the extent to which it is (or would be) a critical problem (if it did exist). The rationale for the two ratings is that it is useful for $D O E$ to know what problems exist to be solved, and what potentially critical problems should be prevented from occurring. Each rating was made on a five-point scale. The description of the scale points is shown in Figure 1. The results, in terms of mean ratings for each of the 27 items are shown in Table 1 .

Highest Priority Problems

None of the problems was seen as being nonexistent or of low importance. All of the means were " 3 " or higher (some agreement that it exists; quite critical if it does exist). Given the distribution of ratings, the following problems are considered to be of highest priority because their rating of either existence or criticalness was 4.2 or higher. These high-priority items are listed from very highest priority downward. All of these items were indicated to be both existing and critical. 
A. Based on your experiences (or information from a reliable source), to what extent do you agree that the following is the case or the situation?

Extent of Agreement that it Occurs:

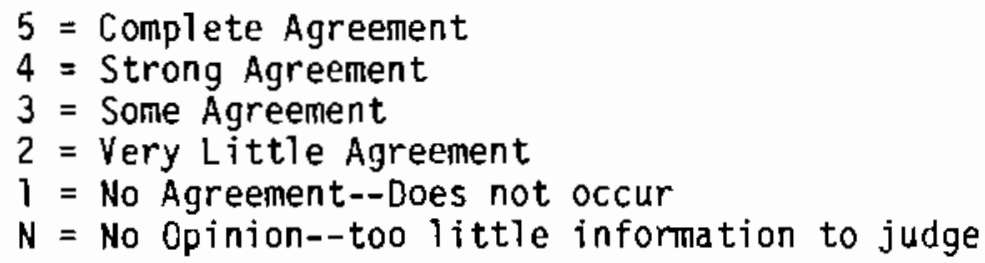

B. Regardless of whether you judge an issue to be occurring or not, to what extent would it be a critical factor hindering positive working relations between DOE and MBs (if it did occur).

Criticalness of Problem:

$5=$ Extremely Critical

4 = Very Critical

3 = Quite Critical

2 = Sonewhat Critical

$1=$ Slightly or Not Critical

$N=$ No Opinion--too little information to judge

FIGURE 1. RATING SCALES FOR MINORITY BUSINESS PROBLEMS 
TABLE 1

NEAN RATINGS OF DOE/MB BUSINESS PROBLEMS

BY MINORITY BUSINESS LEADERS

Problem $^{\mathrm{a}}$

Time-consuming, costly to pursue

Excessive paperwork

Conplicated paperwork

MBs' inability to advertise skills

Too many roadblocks to work with $\mathrm{DOE}$

Lack of fit between needs and services

Inconsistent application of regulations

Buyers' unwillingness to help MBs

Excessive legal requirements

Difficult to get information from DOE

DOE doesn't get word out on opportunities

DOE makes irrelevant requests

Response lead times are too short

Better matching of DOE and MBs needed

Minority designation is a detriment

Prime contractors don't help MBs

MBs can't compete with bigger firms

Contract requirements are not clear Buyers should learn MBs' businesses MBs are not quickly informed of problems

Buyers use MBs to satisfy statistics

MBs need technical assistance from DOE Nonadherence to policy is confusing

Buyers are inconsistent in policy practice

Buyers need to work closely with MBS

DOE should give positive feedback

DOE takes too long to pay
Existence Criticalness

4.2

4.2

3.6

3.4

3.4 *

4.1

$3.4^{\star}$

$3.0^{\star}$

4.2

3.6 *

$3.2^{\star}$

4.1

4.5

$3.3^{\star}$

3.5

4.0

4.1 *

4.3

4.4

$3.5^{\star}$

4.0

4.1

3.4 *

4.3

3.8

$3.5 \star$

4.5

4.8

$3.6^{\star}$

3.6

4.2

$4.0^{\star}$

4.4

4.5

3. 3*

4.2

3.6

3.6 *

4.2

$3.7^{\star}$

4.0

3.8

3.5

4.1

4.3

$3.8 *$

$4.0^{\star}$

4.1
4.1

4.1

4.4

4.0

3.9

4.7

aThe problems are listed in the order in which they were presented to interviewees. The first set of 17 reflected possible pre-contract problems; the latter 10 post-contract problems. Bold type indicates 10 highest-priority items based on their being indicated as existing and critical to positive $M B-D O E$ working relations.

*An asterisk means that there was significant variability among the interviewees' ratings of the problem. Some rated it very high; sone rated it very low. 
1. DOE does not get the word out to MBs about upcoming procurement.

2. MBs cannot competitively bid against bigger companies.

3. Prime contractors don't work enough to help MBs.

4. Costs cannot be sustained because it takes too long to get paid.

5. Buyers are inconsistent in applying policies to work with MBs.

6. It is hard to get infomation about DOE procurements.

7. The inconsistent applications of regulations is confusing.

8. Buyers should learn more about our business.

9. Seeking contracts is time-consuming and expensive.

10. A mechanism is needed to match $M B$ capabilities and DOE needs.

The above high-priority items reflect the full range of issue-categories previously discussed. Problems 1,6 , and 10 clearly relate to the issues of knowledge, communication, and access. Problems 5, 7, and 9 reflect difficulties associated with the solicitation process, as well as some undergirding in buyer attitudes. Problems 2 and 3 concern the broad issue of MB competition with larger organizations. Problem 4 was cited frequently as a major contributor to MBs' financial difficulties. Problem 8 underscores MBs' concerns with buyers' attitudes, motivation, and knowledge about dealing with minority businesses.

Secondary Priority Problems

Eight problem statements were rated from 3.8 through 4.1 on existence or criticalness. This second-level class of problems consists of the following.

1. Levels of cooperation suggest MBs are used to "satisfy statistics."

2. MBs do not know how to advertise their skills.

3. The designation "minority business" is a detriment.

4. MBs could benefit from technical assistance.

5. Procurement officers should give positive feedback on MBs' work.

6. Procurement officers seem unwilling to help MBs in pre-contract phases.

7. Procurement officers should work more and cooperatively with MBs.

8. There are too many roadblocks to working with DOE. 
Most of these problems relate to issues of closer DOE/MB collaboration and support in procurement and working relationships. They also reflect general frustrations in trying to work with DOE and avoid any stigna of their minority classification.

Lesser Priority Problems

The remaining nine problems were rated from 3.0 through 3.6 . It is worth noting that many of these "lesser" priority problems reflect concerns with the procurement process itself, which: (1) based on popular reports and expectations seem quite salient; but (2) take on lesser significance among the MBs themselves. Those problems relate to paperwork, legal requirements, confusing contract terms, lack of fit between DOE needs and MB services, and short lead times for bid responses. This finding also suggests that the $D O E / M B$ problems that are the easiest to resolve (with the proverbial "stroke of a pen") are also the least significant issues for the minority businesses. Resolving the key issues will require longer-term interactive problem-solving anong buyers and between the government and the businesses. 


\section{ISSUES FROM THE PROCUREMENT OFFICERS' PERSPECTIVE}

\section{Attitudes and Support of MBS}

With few exceptions, buyers support and look favorabiy upon MB participation in their business. However, as one would expect, they do so from within a framework of maximizing business efficiency for their organizations. This perspective was echoed by several comments to the effect that when positive relations occur between them and MBs, it is because of the MBs' quality product, competitive price, and responsiveness to the buyers. These are criteria that buyers apply in making buying decisions across-the-board; they try to apply them equally to MBs. Several examples were cited where companies supplying products did so in "good-business" fashion.

In some cases, recognizing that companies are eager to respond to buyers technical needs and schedules, the buyers will "go the extra step" to visit and consult with MBs to help make them competitive, regarding quality assurance or guidance on how to bid. Where permissible, buyers may also make an award to a "number-two" minority bidder, either because the low bidder is not in affirmative-action compliance, or as a supplemental award to get the minority firm started in the buyers' business.

Buyers are naturally more attracted to firms they see as being responsive. Responsive MBs have: followed-through; been open in communications; returned calls; supplied products or referred buyers to others who can; taken faulty products back and resupplied; efficiently expedited deliveries; kept track of their work and let the contract officers know of problems. When such instances occur, buyers enjoy productive relations with MBs, and many of the buyers interviewed reported the general tone that, "most minority businesses do a good job." The chasm is not so big; many buyers and MBs have preconceived notions about each other that are not accurate.

Concerns About $M B$ "Programs" and Goals

Buyers' support of MB participation does not necessarily imply their support of government or company $M B$ "programs" and emphases. While a subtle difference, the distinction accounts for substantial variability in buyers' views toward MBs. Buyers generally believe that MB programs 
should be designed to increase participation, but without price compromises, or setting MBs up for failure through pricing or work specifications. Some also felt that "minority" designations are counterproductive, and MBs should be treated like other small businesses. Minority-specific programs tend, for many buyers, to produce conflicting business goals and added difficulties in performing their jobs. Buyers indicated that "competition" and "minorities" are the two big procurement-contracting issues; but they often see the two issues as representing conflicting decision criteria. Several buyers expressed an intrinsic aversion to $M B$ programs based either on philosophy (al) firms should be equal, not favored) or on practicality ("we take a beating for awarding to a non-minority low bidder"). Goals or quotas force awards to MBs which may conflict with what some buyers see as "good business practice," and take some buying decision power out of the buyers' nands. Some expressed concerns that goals will lead to setting money aside and giving it to "bandits."

No one lobbied for more or stronger government MBE guidelines. Government is seen as giving enough latitude, and problems should be addressed and resolved at the buyer-vendor level. DOE's forcing of $M B$ goals is seen as a disincentive. The operative incentives for buyers are to: (a) reach goals; (b) meet technical objective and price criteria; (c) get an experienced contractor-base; and (d) derive satisfaction from bringing in new contractors.

Even when there is support for the intrinsic value of MB programs, some concerns were expressed about the implementation of those programs. Buyers stressed the importance of having programs that are supported throughout their organizations, starting with top management. In some cases, programs may suffer because buyers are left to their own devices without ongoing attention and assistance. It was suggested that the programs are not given attention until "measuring time"; that is, results are measured against goals, but there is little intervening assistance in meeting the goals. Some buyers also face the classical "changing-standards" problem; when goals are overachieved, new and higher goals are set. Meeting goals can be self-satisfying for buyers.

Supportive attitudes require top-management commitment and treating MBS like any other business, discounting connotations of $M B$ designations. MB 
goals must match business goals so as to avoid an attitude of "what crumbs can I give away without failing?" Buyer professionalism and commitment to socioeconomic goais are seen as counterpoints to such a potential attitude and as a requisite for an effective buyer.

A common problem for buyers in implementing MB goals is the pressure of being the "middleman" between MB-goal emphasis from above and the need to resolve that with the needs of the technical, user staff for whom they are buying. Technicians, researchers, or line managers tend to emphasize "best" quality, and preferred or known sources. This makes it difficult for buyers to emphasize "best price," expand competition, or, in some cases, to overcome users' perceptions of minority-based ventures. They must be responsive to technical people who may not realize contractual matters. Greater acceptance of MBs by technical staff is crucial to program success. This situation is exacerbated by the visibility of minority business fajlures; MBs "do business in a fishbowl," and failures are taken as evidence of the inappropriateness of ib contracting goals; but, on the positive side, MBs' visibility also makes their concerns heard. Buyers also see meeting $M B$ program goals as difficult when few MBs are available in their area of procurement responsibility. This problen was rated as the most severe among the set of issues that buyers were asked to rate (see Table 2). Several buyers noted that the ease of including MBs depends on the type of commodities they are assigned to procure; in the high-technology, technical services, professional research areas, it is most difficult. Easier situations involve office supplies, machine fabrication, and some precision work. Moreover, when a MB tries to cover multiple types of goods provision, it spreads itself too thin and degrades its capabilities. With a relatively small set of potential MBs, it becomes hard to evaiuate MB bids on an individual basis.

Buyers generally see goal-setting as not very successful. Goals are based on total available procurement dollars. Where subcontract goals are set on a total procurement base and most transactions are small in dollar volume, it is difficult to meet even a smail percentage goal. To meet goals, contractors need to involve MBs in bigger-dollar programs. The emphasis on $M B$ goals makes $M B$ involvement a chronic area of vulnerability, and buyers seek to cover themselves. Buyers risk chastisement for making awards to non-minority low bidders when such goals are being emphasized. 
Organizational feedback on minority goals is also variable and few incentives were apparently operative. Goal-performance is usually given attention by management but feedback is slow to come; positive feedback is usually intrinsic, in the form of recognition ("back pats"). Often, performance criteria based on dollars-awarded and effort-expended are mixed in evaluations.

The ease of meeting $M B$ goals was also seen to vary for different types of procurement officers. Subcontract specialists reported having goals built into their performance appraisals. There is often a greater desire to achieve those goals because researchers may push them to succeed to protect their project funds. However, those same researchers may also inhibit goal-achievement by holding preferences for experienced, non-minority subcontractors.

Supportive Regulations

Buyers generally concluded that $M B$ goals should be negotiated and that they should have the tools and money to achieve them. Some of those tools are the regulations with which they work. Most buyers argued for no further change in relevant procurement regulations ("they have changed too much already"). It was similarly felt that one can't legislate good procurement practices, and MB-program problems should be solved voluntarily to avoid legislative mandates. Most buyers prefer to be allowed to operate as commercial firms with general norms and goals. Attempts to simplify regulations, some felt, would glaze over basic problems.

Buyers expressed support of set asides, if there are enough qualified suppliers to generate competition. However, some also argued that set asides should not be restricted to minorities. They prefer telephone bid procedures, where appropriate, and the immediate mutual feedback that such bid-procedures provide; they report success with oral bids under $\$ 70,000$. The buyers saw the primary incentive for increasing MB participation as being one of establishing additional suppliers to enhance competition and eventualiy save them money. In this respect, they prefer to think of MBs not as MBs, but as just another potential business supplier. It was suggested that a standardized bia/application procedure across agencies would help both buyers and $M B$ suppliers to understand and respond to bid 
opportunities. In some cases, it was argued that the buyers' own companies need to clarify and communicate their priorities; one company had government authority to sole-source to MEs on a case-by-case basis within dollar limits, but chose not to implement that authority. That example reflects a general buyer attitude that others need to help; they (buyers) should not be expected to solve the country's business-equity problems.

Government efforts to help MBs should also be scrutinized and properly reinforced, according to some buyers. For example, there was a fairly widespread reaction that 8 (a) small-business programs do not teach MBs to compete, and do not give them adequate preparation for bidding. This often translates to a lack of knowledge of how to bid. Some MBs will simply send a standard brochure in response to an RFP, generating a negative stereotype among buyers.

Some internal initiatives (buyers and their management) could help to reinforce reguiations and $A B$ goals. Management could support achieving $M B$ goals, rather than punishing failure to meet them; they could also give buyers judgment latitude and encourage creativity (one sets a ceiling of $\$$ lOK on buyer judgment); they could provide technical assistance to buyers on working with their technical staff and MBs. Contracts officers might track MB/SB performance and develop a code based on risk (e.g., 1-to-5) for dealing with small (including minority) businesses. One firm currently uses a vendor code designating that they have done business with the $M B$ before. As a stand-alone index, though, this can limit opportunities for new $M B$ suppliers to get the first job. Contractors tend to get a few MBs whom their technical people trust.

Difficulties in Dealing with MBS

Although buyers generally supported MB-participation efforts, they did identify some difficulties based on their experiences with, and perceptions about, MBs. The principle problems were supply of MBs and their knowledge about doing business with DOE (see $i$ tems "not available" and "need technical assistance" in Table 2). Buyers commented that "most MBs are good business people," and their performance is "no better or 
worse than other small businesses." However, buyers have difficulty finding qualified MBs. If the MBs are "contract-savvy," they may be too large to be interested in small-purchase RFPs.

Buyers also expressed some frustration with those MBs that do bid on their work. They related cases of trying to help MBs only to have them send inadequate proposals (general brochures) or fail to followup with bids, without giving any explanations. Such problems are compounded when MBs complain about not getting awards and/or fail to understand the debriefings given to them. Responding to $M B$ concerns costs buyers time and money. At the extreme, such situations generate buyer perceptions that MBs do not follow-through, do not have interest or capabilities, and/or may be looking for "minority-based" handouts; buyers, of course, are averse to any connotation of "giveaway" programs. Such circumstances, when they exist, make it very difficult to break down attitude barriers to buyer-MB collaboration. Some buyers believe that some MBs assume that MBE programs guarantee their success (rather than providing opportunities). Buyers noted that fears of appeals may predispose them to give repeat business to past $M B$ firms they have used.

Two kinds of difficulties occur with MBs who do win contract awards. First, pricing is unrealistic. One expression was that MB responsiveness may mask price tradeoffs. In some cases, MBs abuse pricing and overcharge relative to what buyers could get elsewhere. Ir other cases, MBs don't realize what they're getting into, underprice the work, and eventually fail. Secondly, MBs may fail to deliver appropriately; examples were cited of late delivery or defective quality. In one extreme case, a business simply closed before delivering. Such compliance difficulties were usually attributed to management problems in MBs and buyers' attendant problems of getting good ship dates or explanations of $M B$ problems. Additionally, after initial successes, MBs may expand and spread themselves too thin, rather than staying with their expertise. Because they want the business they get in "over their head" regarding price or delivery without acknowledging inabilities. One buyer worried that "we" buyers abet this by spreading the good word about MBs and getting then into new ventures. MBs of ten become "broker-type," third-party companies without inventory, and they present problems of pricing, leverage, and delivery time. 
A primary buyer concern is that of MBs' capabilities, and knowing when those capabilities are present. Qualified MBs generate positive working relations. Qualified MBs know their products, where to get information, how to efficiently expedite. Local suppliers who have lengthy business records are especially good in that they remain responsive and will take back/redo subpar work. Capabilities involve product knowledge, good organization, and going the extra-step for the buyer. The lack of capabilities often reflects an underlying naivete about government contracting, or lack of expertise for technical (or research) services. Instead of hiding their problems, MBs may not recognize them. MBs were thought to need training/assistance on how to prepare proposals, and buyers need to be taught how to train MiBs to do that; they feit a need to help make libs more competitive.

Assessing $M B$ capabilities is often a problem for buyers. They believe that there are many good MBs, but they must find them "without getting a bad one." For that purpose, they need adequate time, evaluation criteria, and information. They feel they haven't the resources to go out and evaluate $M B S$ from a $Q A / Q C$ perspective.

A summary assessment of the severity of buyer difficulties is shown in Table 2. The buyers, like the MBs, rated problem severity on five-point scales. Table 2 shows the most difficult problems (mean $=3+$ ) to include: lack of available capable MBs; 1ack of information about MBs; MB needs for technical assistance; limited contractual opportunities; MB naivete and inexperience; and failure of MBs to expand to meet needs. Note that the buyers did not rate their own internal policies as severe problems; it was not true (mean <2) that management is not concerned, buyers do not have latitude, or that incentives are lacking. However, the discussions, reported in the foregoing paragraphs suggested that these areas could also be improved.

\section{Tools for Dealing with Problems}

Generaliy, buyers reported that available tools are helpful but don't completely address the problems. The most helpful mechanisms appear to be those related to sourcing MBs. Buyers report success with, and support of, trade fairs, conferences, and similar opportunities to bring $\mathrm{MB}$ suppliers and DOE users together. Such activities are thought to be more 
fruitful when MBS actually meet and talk directly with buyer personnel. Organized training and collaborative efforts can also be useful. Examples include the Partnerships in Trade program, MB seminars for buyers, and buyer involvement in Minority Purchasing Councils. Records-based sourcing systems are occasionally used effectively. Buyers reported that PASS has improved, but they basically use it as a supplement to their own internal information. Such sourcing systems would benefit from more detailed and organized information for different kinds of liB firms. Buyers also reported using manufacturers as direct sources of recommendations for potential MB suppliers of products that those companies make.

Table 2

Mean Ratings by Buyers of Problens in Dealing with Minority Businesses ( $5=$ high; $1=10 \mathrm{w})$

MBs aren't available in specialized areas

4.4

PiBs need technical assistance for doing business with DOE Buyers are not aware of available MBs

MBs don't expand to meet needs

MBs are najve or inexperienced

There aren't enough contracts for using MBs

MBs are more expensive for the same service

Buyers lack capability information on MBS

MBs can't handle government paperwork

MBs don't meet deadiines

MBs hide problems they are having

There are too many MBs wi thout track records

MBs tend to underprice their bids

Prime contractors seem disinterested in MBs

Buyers have no management-latitude in hiring MBs

There is no incentive to contract with MBS

Management is not concerned about $M B$ participation

4.0

3.5

3.4

3.1

3.0

2.9

2.9

2.6

2.6

2.6

2.4

1.8

1.7

1.5

1.4

1.1

Internally, companjes that contract with MBs often have "MB coordinators" who serve as a clearinghouse and facilitator of developing relations with MBs. They may provide information about MBs, encourage and provide incentives for involving MBs. One company reported efforts in getting employee input, and giving annual recognition awards and merit raises for successful use of MBs (however, buyer viewpoints vary on the motivating value of tying pay to MB goals). With such organizational support, buyers take extra "outreach" sorts of steps to communicate their 
expectations to MBs and to assist MBs with some aspects of the paperwork load faced by the MBs. Many libs do not have legal counsel or "government specialists" to do paperwork and may need initial assistance. (Again, though, as a counterpoint, some buyers saw such assistance efforts as "detracting from their [own] productivity.") 
, 


\section{THINKING TOWARD SOLUTIONS}

The display on the following page briefly identifies potential solution strategies for the issues that have been discussed. The strategies generally involve buyer training and supportive actions that OOE could institute or continue. These suggestions are discussed more fully in the companion report, "General Design for a Technical Assistance Program to Help DOE/Prime Contractor Buyers in Doing Business with Smal 1 Disadvantaged Businesses." 


\section{Solution Strategies}

Issues

KNOWLEDGE OF USER NEEDS

Communication-Narketing

Ambiguity. Follow-up.

Central information. Knowing MB Capabilities.

Feedback.

ACCESS TO FIRST CONTRACT

Preferred Suppliers.

Politics. Human Nature.

Flexibility. Risk-taking.

Resistance. Need-match

Sourcing.

BUSINESS COMPETITION

Prices. Stereotypes.

Primes' Exclusion.

MB Abuses. Localism.

SOLICITATION PROCESS

Paperwork. Confusion. Timeliness. Flexibility. Buyer Variability.

FINANCIAL DIFFICULTIES

Bonding. Financing.

Cash Flow. Control.

AWARENESS/SENSITIVITY

Misperceptions. "Traditions." Inconsistency. "Comfort Zones." Sourcing. Networking. Bureaucracy. MB Range and Stability

ATTITUDES/MOTIVATION

Confidence. Neglect.

Inhibition. "Good

Faith?" Buyers in DOE \& Primes. "Inferiority." MBs Easily Taken, $\mathrm{MBE}=$ Welfare. Negative Information 0verweighted.

Game Playing. "Minority" Implications.
Buyer Assistance

Buyer/MB Info Exchange

Giving Feedback

Clarifying Needs

Use PASS

Develop Hultiple Sources

Communicate with Primes

Behaving Flexibly/

Taking Risks

Realistic Expectations

Linking Bigs with MBs

Comrinicating Requests

Clarifying Information

Responsiveness

Flexible Use of Uptions

Buyer Differences Standardization

Evaluating Bids

Acting promptly

Basic Info on MBs

Overcoming Stereotyping

Heightening Sensitivity

Breaking Traditions

Sourcing Mechanisms

Solicit, Organize MB Info

Learning supplier business

Using MBs to Achieve

Own Goals

Honesty/Openness

Supports Protection of

Suppliers (MBs)

Risk-Taking/Communication

Negotiation Skills
Headquarters Actions

True Outreach programs

Publish \& Disseminate

Communicate General Needs

Establish \& Use Central

Source

Improve PASS

Technical Assistance for

Business Development

Set-Aside Guidelines

Waiver Guidelines

Concretize Needs

Publish generic needs

Mandatory goals

Improve certification

Quick-pay provisions

Support bonding, etc.

Technical assis./finance planning

Regular program information meetings 
Solution Strategies

Issues

ACCOUNTAB IL ITY Support. Incentives. Top-level Concern. Evaluation.
Buyer Training

Management Invol vement File-Keeping for Reference \& Development
Headquarters Actions

Goals/Evaluation/Monitoring Buyer Performance Buyer Incentives 
,

4

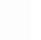




\section{BIBLIOGRAPHY}

Bates, T. Black entrepreneurship and government programs. Journal of Contemporary Studies, 4. 59-69, Fall, 1981.

Cole, R. J. \& Somers, P. Complying with government requirements: The costs to small and larger businesses. Report to the U.S. Small Business Administration. Battelle Human Affairs Research Centers, Seattle, September, 1981.

Dennis, B. K. Strengthening small business participation in DOD extramural $R$ \& D. Proceedings of the Federal Acquisition Research Symposium, Williamsburg, VA, December 7-9, 1983.

Dingle, D. T. New directions for black business. Black Enterprise, August, $1985,16(1), \mathrm{pp} .67,70$.

Girovasi, E. L., Jr. An assessment of the need and impact of PL 95-507: A project in managerial problem solving. Washington, D.C., American University Report 142-80-IX, December, 1981.

Kilgore, P. G. MBE funding in the construction industry: a constitutional question of reverse discrimination. Labor Law Journal, May, 1979, 80, 289-294.

Lusher, E. Women-owned small business: Winning in the federal marketplace: Volume 3 . Technical research report. Belmont, MA. CRC Education \& Human Development, June, 1981.

Norris, William $C$. Innovation is spelled c-o-o-p-e-r-a-t-i-o-n. Business \& Economic Review, July, 1985, 31 (4), pp.29-31, 34 .

Roseblatt, A. 8(a): getting it back on track. Black Enterprise, Oct., $1977, \underline{8}, 32-35$.

Singer, J. W. Using the procurement pot for social and economic goals. National Journal, April, 1979, 11, 564-568.

Tovey, 3. An evaluation of the U.S. Federal Government Programs Available to Aid Small Business in the Energy Area. Small Business

Administration Report, Dec., 1980.

Whitmore, $W$. Taking your business on the road. Black Enterprise, August, 1985,10 (1), pp. $91-92$.

The boomerang effect of a procurement law. Business Week, Aug. 13, 1979, p.29.

Minority firms on local public works projects - mixed results. U.S. General Accounting Dffice, Report to Congress by the Comptroller, January $16,1979$. 
Proposals for minimizing the impact of the 8 (A) program on defense procurement. GA0 report, GAO/PLRD-83-4, October 12, 1982.

SBA's progress in implementing the PL95-507 subcontracting and surety bond wajver provisions has been 1 imited. GAO Report \#CEO-81-151, Sept. $18,1981$.

"A good garage is hard to find." INC, Apri1, 1983.

Minority Business Today, May, 1985. Washington, D.C. U.S. Department of Commerce, Minority Business Development Agency.

Minority Supplier News, Apri1/May, 1985. National Minority Suppliers Development Council.

Minority Business Entrepreneur. Jan/Feb, 1985.

Minority Business Entrepreneur. May/June, $1985^{\circ}$.

Guide to the Defense Contracting Regulations for Small Business, Small

Disadvantaged Business, Women-Dwned Small Business. Washington, D.C. Directorate of SmalT and Disadvantaged Business Utilization, Uffice of the Secretary of Defense.

Report to Congress on the Small Business Program of the DoE. March, 1985.

"Minority firms want bigger shares of garbage business." Seattle Times/Seattle Post-Intelligencer, Sunday, November 10, 1985.

Nationa] Federation of Independent Busness, Issue briefs. Washington, D.C., 1986.

Idaho National Engineering Laboratory, Selling to EG \& G Idaho. Idaho Falls, Idaho, 1986.

U.S. Department of Energy, Program statement. Office of Minority Economic Impact. Washington, D.C., 1985.

U.S. Small Business Administration, Issue briefs and facts. The white House Conference on Smal1 Business, 1986.

U.S. Smal1 Business Administration, The State of Small Business: A Report to the President, May, 1985.

U.S. Department of Energy, Small and/or $5 m a 11 / d i s a d v a n t a g e d$ business: Handbook. Richland operation office, Richland, washington, undated.

U.S. Department of Energy, Guide for the submission of unsolicited proposals. Report No.DOE/MA-0095. Procurement and Assistance Management Directorate, June, 1983.

U.S. Department of Energy, Subcontracting opportunities for disadvantaged businesses. Office of Minority Economic Impact, undated. 
U.S. Department of Energy, No-cost workshop for small disadvantaged business owners. Richtand and Idaho Falls Operations, December, 1985.

U.S. Department of Energy, Feasibility study to develop a marketing plan and strategy for increasing the participation of minority busines enterprises and black colleges and universities in energy-related industries. Report No.DOE/MI/10002-T3. January, 1983.

U.S. Department of Energy, Assessment of subcontracting opportunities for minority owned small business in the Defense Program Division of The United States Department of Energy. Report No.DOE/MI/01000-TI, March, 1981. 
,

- 4

!

(

( 


\section{MINORITY BUSINESSES INTERVIEW GUIDE}

This interview guide is designed to help interviewers in several ways:

- by ensuring that each interviewer covers the same areas with all interviewees

- by aiding interviewers in asking questions in the same manner

In this way, there can be some comparability of information obtained by different interviewers, from different interviewees.

The attached interview guide is divided into the following five sections:

I. INTRODUCTION

II. BACKGROUND INFORHATION

III. GENERAL QUESTIONS

IV. SPECIFIC QUESTIONS

V. WRAP-UP INFORMATION

Responses can be written directly on the interview guide or on attached paper. Please complete answers to all questions or indicate briefly why the interviewee cannot answer the question (e.g., no experience with the issue).

Interviewer

Date 


\section{INTRODUCTION}

The purpose of this interview, as I indicated over the phone, is to assist the Department of Energy with finding ways to improve the working relations between DOE and small minority businesses so that there can be greater involvement of MBs in energy-related business opportunities. Their goal is to identify issues that they can address primarily through a training program for procurement officers. A necessary first step in this process is to attempt to systematically determine what are the types of things that DOE procurement officers can continue doing, stop doing, or do differently in order to enhance working relations with minority businesses. While various individuals have indicated that working relations should be improved, a systematic assessment of what should be done has not been conducted. Therefore, for this project, we have examined information on this topic, reviewed studies conducted at several DOE locations, and are conducting interviews with minority business representatives as well as procurement officers to identify areas that could be addressed as part of training for procurement officers.

We realize that there may be issues of concern to you regarding how to improve relations with DOE that may be "bigger picture" issues that can not necessarily be addressed through a training program, but may require major policy changes. While we would like to hear your views on any "bigger picture" issues, our primary focus is on the kinds of things that could be incorporated into a training program for procurement officers.

Your firm is one of approximately 14 that we randomly selected from a 1 ist of 34 minority businesses in the Puget Sound area. Since it would not be possible to interview all minority businesses that work with DOE, we are relying on a sample of interviews. As such, while we are most interested in your experiences and suggestions, if you have reliable information based on discussions with other minority business firms regarding their dealings with DOE, I would be glad to hear about them also.

None of your comments will be reported to the DOE. We will be summarizing the information obtained from all the interviews, and only summarized information will be provided to DOE. Therefore, you can be assured that your responses will be held in the strictest confidence; we encourage you to be frank with us. 
11. BACKGROUND INFORMATION

The following information is for our purposes only, and will not be reported to the DOE.

A. Name of interviewee

B. Title and address of business (so that a copy of the sumary report can be sent to you)

C. Type of business

D. How long in business

E. Are you certified by some agency? If yes, by whom?

F. How many direct contracts (prime) and subcontracts have you bid on to DOE?

Direct contracts

Subcontracts

G. Approximately what percentage of the DOE direct contracts and subcontracts that you bid on have been awarded to your business?

Direct contracts

Subcontracts

H. When did you first bid on a DOE (sub) contract 
III. GENERAL QUESTIONS

A. Based on your experiences (or information from a reliable source), describe examples of any positive working relations you have had with DOE directly (a DOE procurement officer) or indirectly when working as a subcontractor?

Describe specifically why it was a positive working relation. For each example, describe the circumstances and what exactly $0 O E$ did that was positive.

B. Based on your experiences, describe examples of any negative working relations you have had with DOE directly (a $\overline{\mathrm{DOE}}$ procurement officer) or indirectly when working as a subcontractor?

Describe specifically why it was a negative working relation. For each example describe the circumstances and what exactly DOE did that was negative. 
C. Based on your experiences, what are the most important reasons why DOE/MB working relations are not always successful? Also describe why indirect working relations with DOE, as a subcontractor, are not always successful.

D. Should procurement rules be changed for dealing with minority businesses? If yes, how?

E. What are the most significant hurdles in your view to successfully doing business with DOE directly or indirectly as a subcontractor? How can DOE assist--if they can--with minimizing these hurdles?

F. What is the most helpful tool/program/aspect you have experienced in doing business with DOE? 
IV. SPECIFIC QUESTIONS (ratings)

Use the two rating scales shown below for rating $i$ tems on the following pages:

A. Regardless of whether you judge an issue to be occurring or not, to what extent would it be a critical factor hindering positive working relations between DOE and MBs (if it did occur).

Criticalness of Problem:

$5=$ Extremely Critical

$4=$ Very Critical

$3=$ Quite Critical

2 = Somewhat Critical

$1=$ Slightly or not Critical

$N=$ No opinion - too little information to judge

B. Based on your experiences (or information from a reliable source), to what extent do you agree that the following is the case or the situation?

Extent of Agreement that it Occurs:

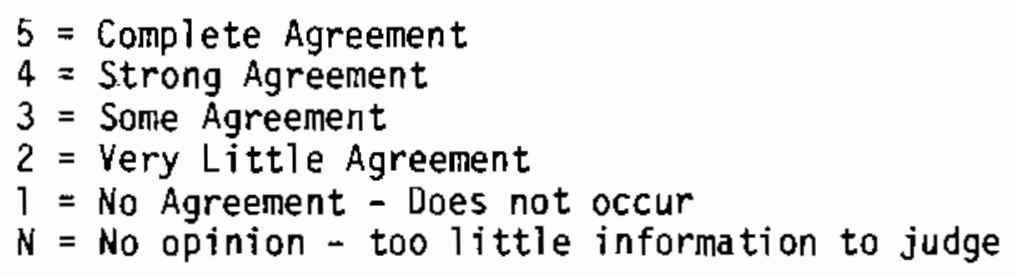

Note: A copy of these two scales is provided at the end of this questionnaire. It can be removed and given to the interviewee for responding more easily. 
QUESTIONS FOR MB (using above two scales for each item)

Pre-Contract

A $\underline{B}$

The process of seeking contracts with DOE is time consuming and expensive.

DOE's paperwork is excessive for responding to RFPs.

DOE's paperwork is complicated, confusing, and/or unclear for responding to RFPs.

MBs don't know how to advertise their skills and products to DOE people.

DOE has too many roadblocks to bother trying to get work with them.

What DOE buys doesn't coincide with the services provided by many MBs--the inconsistent application of 1 aws and regulations of DOE are confusing.

Procurement officers seem unwilling or unable to help us out in the pre-contract phase.

_. DOE's legal requirements are excessive.

It is difficult to obtain information on upcoming DUE procurements.

DOE doesn't get the word out to MBs about upcoming procurements.

DOE sends me RFPs that have nothing to do with my expertise.

DOE doesn't send me RFPs with enough lead-time to respond.

A mechanism is needed that identifies MB capabilities so that they can be matched to specific DOE procurement requirements

The designation minority business is a detriment.

Prime contractors don't work with us enough to help us meet DOE contract requirements.

MBs can't competitively bid against bigger companies that

frequently bid on DOE contracts. 


\section{Post-Contract}

$\underline{A} \underline{B}$

DOE isn't always clear on their requirements once a contract is in place.

After the contract has been awarded to us, the procurement officer should spend some time discussing the work and learning more about our business.

_ DOE doesn't let us know right away when there is a probleri with a contract.

- The level of cooperation given by DOE procurement officers indicate that they work with me to only "satisfy statistics".

- MBs could benefit from technical assistance/training on how to do business with DOE.

DOE frequently doesn't adhere to policies, thus making it unclear as to how to deal with them.

Procurement officers need to work with us more--working with us to solve problems, rather than complaining or belittling us.

Procurement officers should let us know when we are doing our work well.

MBs can't afford to sustain the cost when DOE takes so long to pay ( e.g., a pro-rated payment schedule should be established). 
QUESTIONS OF DOE/PROCUREMENT OFFICER (using the above two rating scales)

\section{Pre-Contract}

A $\underline{B}$

MBs are not always available in specialized areas.

MBs are generally more expensive than other firms for the same quality of service.

MBS can't handle the paperwork required by DOE.

I often lack information on the capabilities of MBs.

I am not always aware of all the MBs that may be able to assist on a project.

Too many MBs without track records makes it difficult to select one for a project.

MBs need technical assistance/training with how to do business with DOE.

MBS generaliy do not expand their services and staffing to meet DOEs future needs.

Prime contractors for DOE act disinterested in having MBs involved on a subcontract basis.

MBs don't have enough contacts with prime contractors to learn about and obtain subcontracts.

\section{Post-Contract}

\section{A $\underline{B}$}

MBs don't meet deadlines on their work.

MBs hide problems until it's too late to have them easily solved.

MBs make unrealistic bids in terms of underpricing, and then don't complete the work (well) when the money runs out.

My management really isn't concerned about how well I work with MBs.

My management won't give me the kind of latitude I need to work successfuliy with MBs.

There is no incentive for involving MBs in our work.

MB management is often too naive or inexperienced to meet our needs. 


\section{RATING SCALES}

Criticalness of Problem:

$5=$ Extremely Critical

4 = Very Critical

$3=$ Quite Critical

2 = Somewhat Critical

$1=$ Slightly or not Critical

$N=$ No opinion - too little information to judge

Extent of Agreement that it Occurs:

5 = Complete Agreement

4 = Strong Agreement

3 = Some Agreement

2 = Very Little Agreement

$1=$ No Agreement - Does not occur

$N=$ No opinion - too little information to judge 
V. INTERVIEW WRAP-UP

At the completion of the interview:

- ask the interviewee if he/she has any questions of you

- provide the person with a business card (and the business card of a Battelle contact for non-Battelle interviewers)

- indicate that a copy of a summary report will be sent to them by December 1985. 
PNL-5811

BHARC-400/86/004

DISTRIBUTION

No. of

Copies

OFFSITE

W. Ballard, Jr.

U.S. Department of Energy Dffice of Energy Programs

Washington, D.C. 20545

30 U.S. Department of Energy Technical Information Center

6 B. McKee

U.S. Department of Energy office of Minority Economic Impact

Washington, D.C. 20545

3. Wright

141636 th Ave.

Seattle, WA 98122
No. of

Copies

ONSITE

1 Richland Operations Office

J. J. Sutey

53 Human Affairs Research Centers

L. R. Radford

L. M. Saari

R. Shikiar

M. T. Wood (48)

HARC Records Center

11 Pacific Northwest Laboratory

J. B. Burmham

M. L. Gragg (3)

Technical Files (5)

Publishing Coordination 
